\title{
IAMJ
}

INTERNATIONAL

AYURVEDIC

MEDICAL JOURNAL

ISSN: $2320-5091$

Impact Factor: 6.719

\section{PRASRAMSINI YONIVYAPADA: A CRITICAL REVIEW}

\section{$\underline{\text { Swati Kimothi }}^{1}, \underline{\text { Pravesh Tomar }}^{2}, \underline{\text { Kapil Yadav }}^{3}$}

${ }^{1}$ Assistant Professor Department of Prasuti tantra \& Stree Roga, MLR Ayurvedic College \& Hospital, Charkhi-Dadri Haryana, India

${ }^{2}$ Professor, Department of Prasuti Tantra \& Stree Roga, Rishikul Ayurvedic College \& hospital Haridwar, Uttarakhand, India

${ }^{3}$ Assistant Professor Department of Kriya Sharira, FIMS SGT university, Gurugram, Haryana, India

Corresponding Author: dr.swati.kimothi@gmail.com

https://doi.org/10.46607/iamj1409032021

(Published online: March 2021)

Open Access

(C) International Ayurvedic Medical Journal, India 2021

Article Received: 10/02/2021 - Peer Reviewed: 14/02/2021 - Accepted for Publication: 17/02/2021

Check for updates

\section{ABSTRACT}

Prasramsini is one of the 20 Yonivyapada mentioned in Ayurveda classics. It was first explained as a Yonivyapada by Acharya Sushruta in Sushruta Samhita Uttartantra 38th chapter "Yonivyapada Pratishedha Adhyaya". It is a condition in which there is displacement of Yoni from its place, excessive vaginal discharges, and difficult labor due to abnormality of passage along with features of Pitta vitiation. On the basis of its description, it can be corelated with $1^{\text {st }}$ and $2^{\text {nd }}$ degree utero-vaginal prolapse. Historical aspect, Nidana, Purvaroopa, Roopa, Saapeksha Nidana (with Mahayoni, Andini, Anatarmukhi, Vatiki yonivyapada) and Chikitsha (Shamana \& Shodhana) of Prasramsini Yonivyapada is explained in detail in this article along with its possible contemporary correlation.

Keywords: Prasramsini; Yonivyapada; Yoni Bhransa, Mahayoni; Andini; Utero-Vaginal Prolapse

\section{INTRODUCTION}

Prasramsini Yonivyapada is one of the 20 Yonivyapada and placed under Pittaja Yonivyapada but as no Yonivyapada can occur without the in- volvement of Vata so it can be considered as Vata Pradhana Pittaja Yonivyapada. 
According to Acharya Sushruta Prasramsini Yonivyapada is one in which there is displacement of Yoni from its place with excessive vaginal discharges because of any irritative conditions due to which labor is also difficult ${ }^{1}$.

\section{Etymology}

Prasramsini is derived from word "Sransi" literal meaning of which is to fall down from its place Meaning of Sransi given in different dictionaries is as follows ${ }^{2}-$

\begin{tabular}{|l|l|l|}
\hline Shabdakalpadruma & Vachaspatya & Shabdasagara \\
\hline 1-Adhah Patansheele & 1- Adhah Patansheele & 1. Falling or hanging down \\
\hline & & 2. Pendulous, depending \\
\hline & 3. Being loosened \\
\hline
\end{tabular}

\section{Historical Aspect}

Following is the short description of past literature on Prasramsini Yonivyapada to explain its historical aspect.

Ayurveda classics like Charaka Samhita, Ashtanga Sangraha, Ashtanga Hridya have not mentioned Prasramsini as separate disease entity but as a symptom like Yonishula, Yonikarkashta, Yonistabhdata etc. which can be found either as a separate symptom or as a symptom or sign under other Yonivyapada.

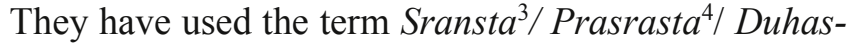
thita Yoni/Nisrata Yoni/Vivrita Yoni/ Sthanapvrita $Y_{\text {Yoni }}{ }^{5}$ etc., for the same condition. Acharya Charaka and Vagbhatta have given treatment for Prasransta Sransta or Sransa, condition of Yoni randomly in chapters where they have explained other Yonivyapada. Acharya Vagbhatta has given Sransta also as a sign of Mahayoni but not as a separate disease entity. ${ }^{6}$ First of all, it was explained as a Yonivyapada by Acharya Sushruta in Sushruta Samhita Uttartantra 38th chapter "Yonivyapada Pratishedha Adhyaya." It was placed under Pittaja Yonivyapada by Acharya Sushruta. ${ }^{7}$ Later on Madhava Nidana ${ }^{8}$, Bhavaprakasha $^{9}$ and Yogaratnakara ${ }^{10}$ have followed Sushruta and described Prasramsini Yonivyapada as separate disease and placed it under Pittaja Yonivyapada.

\section{Synonyms}

Sanskrita - Sransta, Prasransta, Duhasthita Yoni, Nisrata Yoni, Vivrita Yoni, Sthanapavrita Yoni

Hindi - Yoni Bhransa

English -Utero-Vaginal Prolapse
According to Madhukosha commentary it is a condition in which after compression or massage the Yoni is prolapsed. On the basis of its description it can be corelated with $1^{\text {st }}$ and $2^{\text {nd }}$ degree utero-vaginal prolapse.

\section{Nidana}

Hetu or Nidana are the causative factors which are responsible for vitiation of Doshas further on leading to the disease-causing pathologies. Though there are no detailed etiological factors explained by Acharyas specifically for Prasramsini Yonivyapada, there is a common detailed description of Nidana of all Yonivyapada including Prasramsini Yonivyapada. So we can divide Nidana or causative factors of Prasramsini Yonivyapada as follows -

\section{Samanya Nidana}

- These are common for all Yonivyapada

1. Mithya Achara (Abnormal diet and habits) which includes

Mithya Ahara like - Inadequate diet, unhygienic food etc.

Mithya Vihara like

- Coitus in abnormal position

- Use of Apadravya or abnormal substances for sexual pleasures

- Excessive exercises

Mithya Vihara followed by women at the time of Prasava (for example bearing down efforts without presence of contraction)

Improper diet may result in weakness in body and a weak body is more liable to any disease including deficiency and infectious disorders. Improper diet results in deficiency of various essential nutrients in body like minerals and vitamins which are essential for collagen tissue repair and for maintaining natural tone of ligaments and muscles supporting genital organs at 
place. Thus, their deficiency is an important factor for Utero-vaginal Prolapse. Mithya Vihara as mentioned above may cause direct injury to the genital organs further resulting in weakness of genital organs and their supporting structures.

\section{Pradusta Artava}

This may include prolapse due to Estrogen deficient state of body as in post-menopausal women.

With advancement of age, when menopause sets in, estradiol level comes down to basal $20 \mathrm{pg} / \mathrm{ml}$. As estradiol is main hormone for maintaining the elasticity and tone of ligaments and muscles of genital organs, deficiency of estrogen results in atrophic changes to these organs. This post - menopausal atrophy and poor collagen tissue repair with age act as an aggravating factor for prolapse. Decrease vascularity of genital organs, atrophic epithelial changes in lining of genital organs make the organs prone to repeated vaginal infections and UTI which further worsen the condition.

4. Beeja Dosha (Congenital abnormality)

Whenever a woman does Mithya Ahara Vihara, Vatadi Dosha in her body gets vitiated. These vitiated Dosha move on to Rakta and Garbhashaya as a result, when this woman conceives, the Matraja Pitraja Bha$v a$ of developing fetus get Dushita leading to Vikriti in Beeja and Beeja Bhaga Avayava which may lead to defective formation of particular organ (Garbhashaya) and its supporting system along with nerve supply.

Any abnormality of development may cause congenital weakness or absence of ligaments and muscles supporting genital organs. Defective nerve innervation is also a major cause of congenitally weakened support of genital system.

4. Daiva (Due to curses from God)

This may include Utero-vaginal Prolapse of unknown etiology.

\section{Vishesha Nidana}

- These are specific for Prasramsini Yonivyapada.

1. Yoni Kshobhana / Yoni Vimardana

Acharya Sushruta while describing symptoms of Prasramsini Yonivyapada has described "Kshobhana" as single Nidana for Prasramsini Yonivyapada. According to him in this condition any Kshobhana of Yoni can causes Yoni Sransana.
Madhukosha commentary has taken meaning of Kshobhana as "Vimardana" considering it as etiological factor for Prasramsini Yonivyapada.

Madhava Nidana ${ }^{11}$ and Bhavaprakasha ${ }^{12}$ and Yogaratnakara ${ }^{13}$ have followed Sushruta.

On detailed study following reasons are found responsible for the condition of yoni sransa -

Vyavaayam Ati Triptaaya

When a woman indulges in coitus in abnormal positioning after excessive intake of food her Vayu gets vitiated and causes Antaramukhi Yonivyapada which is a condition of abnormal positions of Yonimukha.

Vishama Dukha Saiyyaa Maithunata

$>$ Coitus in troublesome bed also leads to vitiation of Vata which further leads to Mahayoni which is condition of procidentia

Atikaaya grahitaayas tarunyaa

$>$ When a woman of very young age indulges in coitus it leads to Andini Yonivyapada in which prolapsed yoni resembles an egg shape.

\section{Purvarupa}

Purvarupa is one which originates before the onset of a proper disease. ${ }^{14}$ As there is a very small description given about Prasramsini Yonivyapada in the Ayurve$d a$ classics, so there is no description of the Purvarupa for the disease in the classics. However, symptoms mentioned in Antaramukhi Yonivyapada can be taken as Purvarupa of Prasramsini Yonivyapada. Antaramukhi Yonivyapada can be considered as abnormal position of Garbhasaya which is most commonly found in retroverted position of uterus. Due to loosening of its support, uterus almost always undergoes some sort of retroversion before descending into vagina so Antaramukhi denotes previous stage of Prasramsini Yonivyapada. On this basis Purvarupa of Prasramsini Yonivyapada can be summarized as follows-

1. Yoni Shula

2. Maithuna Asahinshnuta (dyspareunia)

\section{Rupa}

When prodromal symptoms show their proper effect or symptoms, it is considered as Rupa.

Following are the Lakshana or Rupa of Prasramsini Yonivyapada 
1. Yoni Sransana/Syandana - Prolapse or displacement of Yoni /excessive discharges

According to Acharyas in this condition any irritation causes displacement of yoni along with excessive vaginal discharges.

Acharya Sushruta has mentioned Yoni Syandana while Madhava Nidana, Yogaratnakara and Bhavaprakasha have mentioned Sransana in place of Syandana. As Yonivyapada name is Prasramsini so Yoni Sransana seems more acceptable. Commentator Madhukosha have mentioned the 'Svasthanachyavate' term for this condition.

2. Duhaprasushcha - difficult labor

As Prasramsini Yonivyapada denotes descended position of Yoni so due to abnormality of passage labor is always difficult in Prasramsini Yonivyapada.

\section{Features of Pitta vitiation}

As Prasramsini is placed under Pittaja Yonivyapada so features of Pitta vitiation are found in this like osha chosa etc.

\section{Differential Diagnosis}

On detailed study of Yonivyapada it was found that there are also other Yonivyapada in Ayurveda where Yoni Sransa is a Lakshana including Prasramsini ${ }^{15}$. So, it's necessary to differentiate Prasramsini Yonivyapada from these other Yonivyapada as management of all these Yonivyapada is different. On the basis of Pradhana Dosha involved, Nidana and Lakshana we can differentiate Prasramsini from these other Yonivyapada.

\begin{tabular}{|c|c|c|c|c|}
\hline Yonivyapada & Pradhana Dosha & Nidana & Lakshana & Probable co-relation \\
\hline Prasramsini & Vata Pitta & Yoni Kshobhana & $\begin{array}{l}\text { 1.Yoni Sransana/Syandana } \\
\text { 2.Duhaprasushcha } \\
\text { 3. features of Pitta vitiation }\end{array}$ & $\begin{array}{l}\text { Utero-vaginal prolapse of } \\
1^{\text {st }} \& 2^{\text {nd }} \text { degree }\end{array}$ \\
\hline Antaramukhi & Vata & $\begin{array}{l}\text { coitus in abnormal posi- } \\
\text { tioning after excessive } \\
\text { intake of food }\end{array}$ & $\begin{array}{l}\text { 1.Vakra Yoni } \\
\text { 2.Maithuna Asahinsnuta } \\
\text { 3. features of Vata vitiation }\end{array}$ & $\begin{array}{l}\text { Retroversion of uterus (can } \\
\text { be taken as Purva Awastha } \\
\text { of Prasramsini) }\end{array}$ \\
\hline Mahayoni & Tridosha & $\begin{array}{l}\text { Coitus in troublesome } \\
\text { bed }\end{array}$ & $\begin{array}{l}\text { 1.Vivrita Yoni } \\
\text { 2.Parva Vakshana Shula } \\
\text { 3.Painful menstruation } \\
\text { 5.Mix features of all three } \\
\text { Dosha }\end{array}$ & Procidentia \\
\hline Andini & Tridosha & $\begin{array}{l}\text { vaginal tear due to coital } \\
\text { activity at a very young } \\
\text { age }\end{array}$ & $\begin{array}{l}\text { 1.Anda samana Yoni } \\
\text { 2.Mix features of all three } \\
\text { Dosha }\end{array}$ & Cystocele/rectocele \\
\hline Vatiki & Vata & $\begin{array}{l}\text { Vata Prakopaka Ahara } \\
\text { Vihara Sevana }\end{array}$ & $\begin{array}{l}\text { 1.Yoni Bhransa } \\
\text { 2.Features of Vata vitiation }\end{array}$ & $\begin{array}{l}\text { Prolapse in menopausal } \\
\text { women due to estrogen } \\
\text { deficiency }\end{array}$ \\
\hline
\end{tabular}

\section{Management}

Treatment given can be broadly classified as-

1. General

2. Specific

\begin{tabular}{|l|l|}
\hline Churna & $\checkmark$ Pushyanuga Churna \\
\hline Sneha & $\checkmark$ Brihata Shatavari Ghrita, Phalaghrita, Laghuphalaghrita \\
\hline Kwatha & $\checkmark$ Nyagrodhadi Kwatha, Maharasnadi Kwatha \\
\hline Modaka & $\checkmark$ Jeerakadi Modaka \\
\hline
\end{tabular}

Specific:_Treatment given specifically for Prasramsini

Yonivyapada

2. Shodhana Chikitsa

It can be further classified into

\section{Shamana Chikitsa.}

Oral-

\section{Shamana Chikitsa}


- To consume meat soup of Gramya, Anupa and Audaka animals.

- Use of milk medicated with Dashamula Kwatha.

- Use of Laghuphalaghrita. ${ }^{17}$

- Sneha medicated with decoction and paste of Dashamula and Trivrita ${ }^{18}$.

Local - (for local application in yoni)

- Paste of Bitter gourd and Water. ${ }^{19}$

- Paste of Indragopa (a type of insect) with Water. ${ }^{20}$

- Paste of Mango seed mix with equal amount of Camphor and Honey ${ }^{21}$

- Oleation (with Trivrita Sneha)

- Sudation (with Milk)

- Replacement of displaced Yoni - After oleation and sudation, prolapsed mass should be gently inserted inside vaginal canal with hand, a ball of Vesawara should be inserted in the canal and finally a bandage should be applied. ${ }^{22}$ The bandage should be removed when patient has desire or feeling of micturition.

The oleation and sudation can be used alone or along with replacement of Yoni. It depends upon degree and condition of prolapse whether there is need of replacement or bandaging of Yoni or not.

\section{Sodhana Chikitsa}

Sodhana Chikitsa mentioned by Acharyas in Prasramsini Yonivyapada are-

\section{Uttara Basti}

2.Anuvasana Basti

Following are the drugs mentioned for Uttara Basti \& Anuvasana Basti in Prasramsini Yonivyapada.

\section{$>$ Trivrita Sneha ${ }^{23}$}

D Sneha medicated with decoction and paste of Dashamula and Trivrita Sneha ${ }^{24}$

> Shatapaka or Sahastrapaka Vatahara Taila, Sukumara Taila, Bala Taila or Shirisha Taila

\section{Contemporary View of Prasramsini Yonivyapada}

Considering all above facts Prasramsini Yonivyapada appears to be description of 1 st and $2^{\text {nd }}$ degree Uterovaginal Prolapse. However, as the word Yoni refers to vaginal canal and uterus, thus prolapse of vaginal wall and uterus both can be considered. Utero-vaginal prolapse can be defined as descent of the anterior vaginal wall, posterior vaginal wall, uterus (cervix), the vaginal apex, alone or in combination.
Main etiological factors involved are trauma of vaginal delivery, congenital weakness and postmenopausal atrophy.

Pathophysiology: Pelvic organ support is maintained by complex interactions among the pelvic floor muscles, pelvic floor connective tissue, and vaginal wall. These work in concert to provide support and also maintain normal physiologic function of the vagina, urethra, bladder, and rectum. Following factors are implicated in failure of this support as a whole, but none fully explain its pathogenesis. These includegenetic predisposition, loss of pelvic floor striated muscle support, vaginal wall weakness, and loss of connective attachments between the vaginal wall and the pelvic floor muscles and pelvic viscera.

Clinical features of utero-vaginal prolapse consists Feeling of something coming down per vaginum, Backache or dragging pain in pelvis, Dyspareunia ,Urinary symptoms (in presence of cystocoeledifficulty in passing urine, urgency and frequency),Bowel symptoms (in presence of rectoceledifficulty in passing stool),excessive white or blood stained discharge per vaginum is due to associated vaginitis or decubitus ulcer.

Treatment option available is oestrogen replacement therapy, pessary application and surgical repairs.

\section{CONCLUSION}

Prasramsini is Vata Pradhana Pittaja Yonivyapada first of all explained by Acharya Sushrut. General etiological factor consists of Mithya Ahara Vihar, Pradusta Artava, Beeja Dosha and Daiva Prakopa. Main etiological factor involved is Yoni Kshobhan due to any reason, resulting in Yoni Srans (utero-vaginal displacement) and Duhprasooshcha (difficult labour). Differential diagnosis can be made with Antarmukhi, Mahayoni, Andini and Vatiki Yonivyapada due to different way of management given for each one. Treatment options described in Ayurveda are many from systemic to local in form of shamana and shodhana chikitsha. On reviewing its description Prasramsini Yonivyapada seems a description of utero-vaginal prolapse of $1^{\text {st }}$ and $2^{\text {nd }}$ degree. 


\section{REFERENCES}

1. Kaviraj Ambika Dutta Shastri, Susrut Samhita Of Maharsi Susruta, Edited with Ayurveda Tattva Sansandipika, Part 2, Chaukhamba Sanskrit Sansthan Varanasi Edition: Reprint, 2006 Uttartantra Chapter 38 Shloka 13, Page 158.

2. Srijan Jha, E-Book of Amarkosha, Shabdakalpadruma, William, Apte. Mumbai, Rastriya Sanskrit Sansthan.

3. Dr.Gangasahaya Pandeya The Charaka Samhita Of Agnivesa, Revised By Charaka And Drdhabala With The Ayurveda -Dipika Commentary Of Cakrapanidatta And With Vidyotini Hindi Commentary By Pt. Kasinatha Sastri, Foreword By Vaidya Yadavji Trikamji Acharya, Introduction By Acharya Priyavrata Sharma, Part 2, Published By Chaukhamba Sanskrit Sansthan, Varanasi, Reprint Edition 2006, Chikitsa Sthan Chapter 30, Shloka No.111, Page No.766

4. Dr. Gangasahaya Pandeya The Charaka Samhita Of Agnivesa, Revised By Caraka And Drdhabala With The Ayurveda -Dipika Commentary Of Cakrapanidatta And With Vidyotini Hindi Commentary By Pt. Kasinatha Sastri ,Foreword By Vaidya Yadavji Trikamji Acarya ,Introduction By Acarya Priyavrata Sharma, Part 2,Published By Chaukhamba Sanskrit Sansthan, Varanasi, Reprint Edition 2006, Chikitsa Sthan Chapter 30, Shloka No.113 Pageno.766

5. Vaidya Yadunananda Upadhyaya Ashtangaahrdayam Of Vagbhata Edited with Vidyotini Hindi Commentary by Kaviraja Atrideva Gupta, Edited By, Published By Chaukhamba Sanskrit Sansthan, Varanasi, Reprint Edition 2006 Uttar Sthan Chapter 34 Shloka 25, 26 Page 572

6. Vaidya Yadunananda Upadhyaya, Ashtanga Hrdayam Of Vagbhata Edited With Vidyotini Hindi Commentary By Kaviraja Atrideva Gupta, Published By Chaukhamba Sanskrit Sansthan,Varanasi, Reprint Edition 2006 Uttar Sthan Chapter 33 Shloka 40, 41page 569

7. Kaviraj Ambika Dutta Shastri Susrut Samhita Of Maharsi Susruta, Edited with Ayurveda Tattva Sansandipika By, Part 2, Chaukhamba Sanskrit Sansthan Varanasi Edition: Reprint, 2006 Uttartantra Chapter 38 Shloka 6,7.

8. Shri Madhavakara, Madhava Nidana With Madhukosa Sanskrit Commentary by Shri Vijayarakshita And Shri Kanthadatta With Vidyotini Hindi Commentary by Shri Sudarshan Sastri Chaukhamba Publicasion Varanasi. $62 / 6,7$
9. Shri Bhavmisra, Bhava Prakasha. Voume 2 Chaukhamba Publication Varanasi Chikitsha 70/8.

10. Vaidya Laxmipati Shastri, Yoga Ratnakara With Vidyotini Hindi Commentary, Published By Chaukhamba Prakashan,Reprinted 2017 Yoniroga.

11. Shri Madhavakara, Madhava Nidana With Madhukosa Sanskri Commentary by Srivijayarakshita And Shri Kanthadatta With Vidyotini Hindi Commentary By Sri Sudarshan Sastri Chaukhamba Publicasion Varanasi.

12. Shri Bhavmisra, Bhava Prakasha. Voume 2 Chaukhamba Publication Varanasi. Chikitsha 70/8

13. Vaidya Laxmipati Shastri, Yoga Ratnakara With Vidyotini Hindi Commentary, Published by Chaukhamba Prakashan, Reprinted 2017 Yoniroga Shloka 9 Page 404

14. Dr. Gangasahaya Pandeya. The Charaka Samhita Of Agnivesa, Revised By Caraka And Drdhabala With The Ayurveda -Dipika Commentary Of Cakrapanidatta And With Vidyotini Hindi Commentary By Pt. Kasinatha Sastri, Foreword By Vaidya Yadavji Trikamji Acarya, Introduction By Acarya Priyavrata Sharma, Part 2, Published By Chaukhamba Sanskrit Sansthan, Varanasi, Reprint Edition 2006, Nidana Sthan Chapter 1, Shloka No.8, Pageno.467.

15. Trivedi Bharvi Bansilal. Uttar Basti - A Therapeutic Measure In Yonivyapada. J Ayurveda Integr Med Sci 2017;

2:220-223.

Http://Dx.Doi.Org/10.21760/Jaims.V2i2.7732

16. Prof (Km.) Premvati Tewari, Ayurvediya Prasuti Tantra Evam Stri Roga Part 2, Stri Rog, Published By Chaukhamba Orientalia Varanasi Second Edition 2000 Reprint 2005, Chapter 1 Page 74- 81

17. Dr. Smt. Shailajasrivastava, Sharngadhar Samhita Of Acharya Sharngdhar, "Jiwanprada" Hindi Commentary Fourth Edition, Chaukhamba Orientalia Publication, Madhya Khand, $9^{\text {th }}$ Chapter, Shloka No.88-91, Page 227.

18. Kavirajaatrideva Gupta, Ashtanga Sangraha Of Vagbhatacharya With Hindi Commentary, Published by Chaukhamba Krishndas Academy, Varanasi. Uttar Tantra Chapter39, Page No.336, Shloke 42

19. Dr. Indra Dev Tripathi, Rasaratna Samuchchaya Of Vagbhatacharya Translated with Rasprabha Hindi Commentary, Published by Chaukhamba Sanskrit Bhawan Varanasi. Chapter 22 Shloka 124, Page 299.

20. Dr. Indra Dev Tripathi Rasaratna Samuchchaya Of Vagbhatacharya Translated with Rasprabha Hindi Commentary, Published by Chaukhamba Sanskrit Bhawan Varanasi. Chapter 22shloka 125, Page 299. 
21. Dr. Indra Dev Tripathi Rasaratna Samuchchaya Of Vagbhatacharya Translated with Rasprabha Hindi Commentary, Published by Chaukhamba Sanskrit Bhawan Varanasi. Chapter 22shloka 126, Page 299.

22. Kaviraj Ambika Dutta Shastri, Susrut Samhita Of Maharsi Susruta, Edited With Ayurveda Tattva Sansandipika, Part 2, Chaukhamba Sanskrit Sansthan Varanasi Edition: Reprint, 2006 Uttartantra Chapter 38, Shloka 28,29

23. Shri Madhavakara, Madhava Nidana With Madhukosa Sanskrit Commentary by Shri Vijayarakshita And Shri Kanthadatta With Vidyotini Hindi Commentary by Shri Sudarshan Sastri Chaukhamba Publicasion Varanasi. Chapter 62 Shloka 6,7

24. Shri Bhavmisra, Bhava Prakasha. Voume 2 Chaukhamba Publication Varanasi Chikitsha Sthaan Chapter 70, Shloka No. 8.

\section{Source of Support: Nil}

\section{Conflict of Interest: None Declared}

How to cite this URL: Swati Kimothi et al: Prasramsini Yonivyapada: A Critical Review. International Ayurvedic Medical Journal \{online\} 2021 \{cited March, 2021\} Available from: http://www.iamj.in/posts/images/upload/601_607.pdf 